\title{
Devonian-Carboniferous boundary sections in Iran
}

\author{
Peter Königshof $^{1}$ (D) $\cdot$ Ali Bahrami ${ }^{2} \cdot$ Sandra I. Kaiser $^{3}$
}

Received: 5 April 2019 /Revised: 4 March 2020 / Accepted: 24 June 2020 / Published online: 30 September 2020

(C) The Author(s) 2020

\begin{abstract}
Many sections are known from Iran which exhibit sediments across the Devonian-Carboniferous (D-C) boundary. In contrast to the majority of published D-C sections worldwide from pelagic/hemipelagic environments, successions in Iran are mainly composed of shallow-water sediments. Correlation with hemipelagic or pelagic palaeoenvironments remains difficult due to biostratigraphic uncertainties in most sections and/or hiatuses. On the other hand, a limited number of sections dealing with shallow-water facies settings in Iran at this particular time period are known and further research is necessary. Several sections in the Alborz Mountains provide an excellent opportunity to study successions across the D-C boundary in shallow-water facies. In Iran, protognathoids are represented by Protognathodus meischneri and Protognathodus collinsoni. The two biostratigraphically important protognathoids (Protognathodus kuehni and Protognathodus kockeli) were not reported or did not occur for the first time in the Late Tournaisian. Early siphonodellids were described instead. In the frame of an Iranian/German research project, we study different palaeoenvironments to reduce serious palaeoenvironmental and palaeogeographical sampling bias which may limit our knowledge on the Hangenberg Event particularly in shallow-water facies. We present a summary on published D-C sections in Iran (Ghale-Kalaghu, Howz-e-Dorah 1, Howz-e-Dorah 2 and Shahmirzad) and sections which are under study (Mighan, Chelcheli and Khoshyeilagh) at the time of this writing.
\end{abstract}

Keywords Hangenberg Crisis $\cdot$ Shallow-water palaeoenvironments $\cdot$ Conodonts $\cdot$ Alborz Mountains $\cdot$ Shotori Range

\section{Introduction}

Based on recent discussions on climate change, the study of extinction events, dynamics and reasons for environmental and climate changes in Earth's history is of fundamental importance. The Devonian-Carboniferous (D-C) transition is one

This article is a contribution to the special issue "Global review of the Devonian-Carboniferous Boundary".

Peter Königshof

peter.koenigshof@senckenberg.de

Ali Bahrami

Bahrami_geo@yahoo.com

Sandra I. Kaiser

sandra.kaiser@smns-bw.de

1 Senckenberg Research Institute and Natural History Museum, Senckenberganlage 25, 60325 Frankfurt am Main, Germany

2 Department of Geology, Faculty of Science, University of Isfahan, Isfahan, Iran

3 State Museum of Natural History Stuttgart, Rosenstein 1, 70191 Stuttgart, Germany of the most interesting time slices in Earth's history as this period was characterised by extreme climate and faunal changes which led to the end-Devonian biodiversity crisis. Based on the ecological severity index by McGhee et al. (2013), the end-Devonian extinction is known as the fourth severe mass extinction in Earth's history. This first-order mass extinction eliminated nearly $20 \%$ of marine invertebrate genera and reduced the long-term biodiversity of all vertebrates by about 50\% (Sepkoski 1996; Walliser 1996; Sandberg et al. 2002). As shown in the review paper by Kaiser et al. (2016), these estimates are poorly constrained for many fossil groups and much more work is necessary (for instance, in shallowwater realms) to get a better understanding of the complex interactions between palaeoclimate dynamics, palaeoecosystem changes and faunal diversity.

The D-C transition is characterised by several transgressive/regressive cycles, and widespread ocean anoxia has been recognised along continental margins or epicontinental basins known as the Hangenberg Black Shale (HBS) Event. Close to the D-C boundary, a major sea level fall (Hangenberg Sandstone (HSS) Event) of more than $100 \mathrm{~m}$ (Kaiser et al. 2016) can be recognised in many sections around the world. Deposition of these black shales and sandstones is known as 
early and middle phases of the Hangenberg Crisis as defined by Kaiser et al. (2016) and Becker et al. (2016). The classic hemipelagic "Rhenish standard succession" of the Drewer section in the Rhenish Massif (Germany) exhibits the characteristic succession of the Hangenberg Crisis and was used to correlate different D-C sections from epicontinental basins and continental margins elsewhere (see summary by Kaiser et al. 2016). Depending on facies setting, equivalents of the regressive Hangenberg Sandstone Event can also be recognised as an unconformity and/or reworked sediments as shown by Cole et al. (2015), Bábek et al. (2016) and Kaiser et al. (2016). Stratigraphical gaps and non-deposition related to this major regression are also known from Eastern Iran (Bahrami et al. 2011). This eustatic sea level fall (HSS Event) might be associated with a glaciation on Gondwana. Evidence for this hypothesis is based on sedimentological as well as palaeontological criteria, and data are published from South America, North Africa and the Appalachians (e.g. Isaacson et al. 1999, 2008; Streel et al. 2000, 2001; Caputo et al. 2008; Brezinski et al. 2010; Lakin et al. 2016). Based on these data in combination with the magnitude of the sea level change, glaciation seems to be the main reason for that major eustatic sea level fall. However, the trigger mechanisms for anoxia and glaciation at the D-C boundary are discussed controversially and require further research. Regarding the latter one, it seems likely that widespread volcanism at that time was underestimated as there is a lack of large igneous provinces preserved in the rock record. On the other hand, evidence of widespread volcanic activity (pyroclastic ash flow deposits) around the D-C boundary is known from many countries such as in Germany, Spain, Uzbekistan, South China, Vietnam and Mongolia (Bai 2001; Liu et al., 2016; Komatsu et al. 2014; Lai et al. 2014; Racki et al. 2018a; Paschall et al. 2019; Stribrny et al. in press).

The D-C boundary has been defined on conodont biostratigraphy from the Global Stratotype Section and Point (GSSP) location La Serre Trench E' section in the Montagne Noire, France, where it is based on the first appearance of the basal Carboniferous conodont Siphonodella sulcata (Flajs and Feist 1988; Paproth et al. 1991). However, under the state of taxonomic knowledge when the GSSP was established at La Serre, the definition of the D-C boundary, and the stratotype section itself, is considered problematic to maintain. The early siphonodellids are taxonomically difficult to distinguish, and therefore, morphotype groups were established for the more precise discrimination of phylogenetically early and late faunas (Kaiser and Corradini 2011).

Therefore, the GSSP position has to be re-located at La Serre (Kaiser 2009), or the D-C boundary needs to be re-evaluated, either by new biostratigraphic indicators (Aretz 2013; Corradini et al. 2016) or by a combined biostratigraphic and sedimentological set of criteria (e.g. Becker et al. 2016). Another problem is obviously caused by the palaeogeographic sampling bias as the majority of investigated sections are from epicontinental basins and continental margins, whereas from shallow-water successions, detailed descriptions are limited. In this report, we use the revised conodont biozonation published by Spalletta et al. (2017) until the first occurrence of Siphonodella praesulcata, then we continue to apply the conodont biozonation published in Kaiser et al. (2009) which means praesulcata Zone (old Lower praesulcata Zone), $c k \mathrm{I}$ (extinction-based costatus-kockeli Interregnum), kockeli Zone (old Upper praesulcatus Zone) and sulcata/kuehni Zone (old sulcata Zone). This is due to the fact that Spalletta et al. (2017) delete the praesulcata Zone, and the ultimus Zone includes the praesulcata Zone and the $c k I$. Thus, the conodont biozone ranges of Kaiser et al. (2009) and Spalletta et al. (2017) are not congruent.

In this report, we present the state-of-the-art DevonianCarboniferous boundary (DCB) in Iran. But, we do not describe all sections which exhibit Devonian and Carboniferous rocks across the D-C boundary in Iran due to large hiatuses close or around the D-C boundary and/or limited stratigraphy. In that case, we refer to relevant references. Most D-C sections in Iran are composed of shallow-water sediments, but some have potential to define the D-C boundary in palaeoenvironmental settings, of which we have a lack of information. Herein, we summarise published data of Bahrami et al. (2011) and provide new data on sections under study (Mighan, Chelcheli and Khoshyeilagh) in shallow-water facies.

\section{Geological background}

During the Palaeozoic, Iran was located at the northern margin of Gondwana (Berberian and King 1981; Scotese 2001). A small area in the north-east, the Kope-Dagh, was part of Laurussia (Berberian and King 1981). According to Golonka et al. (1994), most of Iran in the mid-Palaeozoic was located about $20-25^{\circ}$ south of the palaeoequator. Upper Devonian and Carboniferous rocks are widespread in Iran but often belong to different structural units, and therefore, correlation is difficult. Iran can be subdivided into several structural units, some of which are separated by suture zones (Alavi 1991; Davoudzadeh 1997; Stöcklin 1968). The most important structural units are (a) the Zagros fold belt; (b) the central domain, comprising the southern Alborz Mountains, northwestern Iran and the Binalud Mountains in Eastern Iran; (c) the northern Alborz Mountains with the Caspian Depression; and (d) the east-Central Iran microplate (Fig. 1).

A number of sections across the D-C boundary in Iran were studied in the last decades, providing very variable information on the quality and quantity of different fossil groups, and limited information on geochemical proxies and sedimentology/facies is available. The sections summarised herein concentrate on successions across the D-C boundary even if some sections have a much larger stratigraphic range as it is 


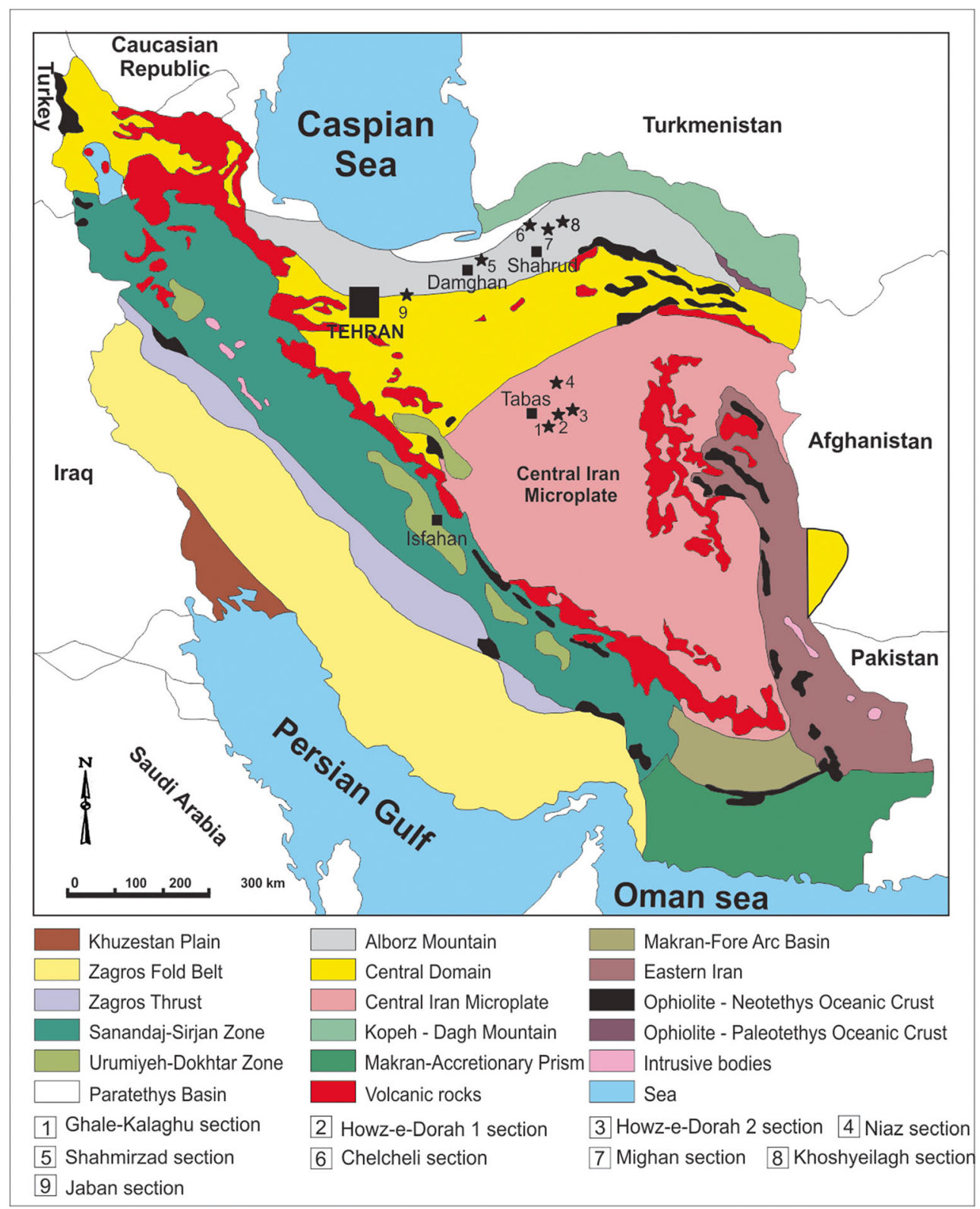

Fig. 1 Structural units of Iran with the position of the most useful D-C sections

shown herein. The sections described are already published and/or sections are under study, and some can be used to determine the D-C boundary based on Siphonodella sulcata. But, much biostratigraphic work is necessary in order to get a well-constrained DCB level and, thus, a profound overview on the Hangenberg Crisis in Iran. Our publication did not consider short reports and/or comments providing less detailed information on the D-C boundary and some unpublished master's theses and reports which have only been partly accessible. We summarise sections from the Central Iran (Shotori Range) and the Alborz Mountains, and we provide an improved correlation chart of most important D-C sections in Iran.

\section{D-C boundary sections in Iran}

\section{Shotori Range}

The Shotori Range belongs to the east-Central Iran microplate which was situated approximately $33^{\circ} \mathrm{S}$ of the palaeoequator in the Carboniferous (Golongka 1994). The area was part of the western Palaeo-Tethys, covered by a large shelf sea, and sediments were mainly formed in shallow neritic palaeoenvironments (e.g. Wendt et al. 2002, 2005). Several D-C localities were studied in the Shotori Range in the last decades with a special focus on different fossil groups (e.g. Ashouri 1990, 1997a, b, 1998, 2002, 2004, 2006; Ghavidel-Syooki and Moussavi 1996; Ashouri and 
Yamini, 2006; Yazdi 1999; Yazdi and Turner 2000; Wendt et al. 2005; Bahrami et al. 2011). Due to the overall shallow-water palaeoenvironments of sections in the Shotori Range, a remarkable stratigraphical gap of variable range around the D-C boundary was proposed by several authors (Ashouri 1995, 1997b; Yazdi 1999; Wendt et al. 2005). Based on more detailed sampling, Bahrami et al. (2011) described three sections in the southern Shotori Range (Ghale-Kalaghu section, base of the section $33^{\circ}$ $20^{\prime} 40.86^{\prime \prime} \mathrm{N}, 57^{\circ} 20^{\prime} 09.72^{\prime \prime} \mathrm{E}$; Howz-e-Dorah 1 section, base of the section $33^{\circ} 22^{\prime} 21.07^{\prime \prime} \mathrm{N}, 57^{\circ} 20^{\prime} 22.85^{\prime \prime}$ E; Howz-e-Dorah 2 section, base of the section $33^{\circ} 22^{\prime} 16.67^{\prime \prime} \mathrm{N}, 57^{\circ} 20^{\prime} 23.0^{\prime \prime} \mathrm{E}$ ) with a focus on conodont stratigraphy. The authors describe conodont assemblages from each section (Fig. 2a-c), but the paper lacks detailed information on a sedimentological/facies description and other fauna. Furthermore, no information is provided on geochemical proxies.

The investigated sections of the Shotori Range exhibit a continuous sedimentological record except a small hiatus close to the D-C boundary which covers the upper part of the praesulcata Zone and, most probably, the lower part of the sulcata Zone (Bahrami et al. 2011). However, due to different terminologies concerning the praesulcata (old Lower praesulcata) or kockeli Zone (old Upper praesulcata Zone), the stratigraphic range of the hiatus is not evident currently.

The stratigraphical gaps are in compliance with the sedimentological record. Around the D-C boundary, oolites and gypsiferous shales occur. Due to the overall shallow-water palaeoenvironments, the conodont record is not abundant and the faunas of the three sections are mainly composed of shallow-water genera (Bahrami et al. 2011) whereas pelagic index species are scarce (e.g. only one Siphonodella sulcata occurs in each section). However, previous biofacies models and concepts are recently under considerations (see discussions in Kaiser et al. 2017), and the occurrence of Siphonodella, which was regarded previously as pelagic fauna, and Protognathodus, which was considered previously as shallow-water fauna, is more likely due to biotic opportunism rather than sea level indicator (Kaiser et al. 2019). In the study by Bahrami et al. (2011), the authors used species of Polygnathus and Pseudopolygnathus to identify the zonal boundaries. Macrofauna such as brachiopods, corals and ostracods occur in all sections but have not been studied systematically. The number of ostracod specimen is high, but in comparison to other shallow-water sections of late Famennian age from Mongolia (Nazik et al. in press), the ostracod fauna from Iran is less diverse.

Vertebrates were investigated in the Howz-e-Dorah section and in the Kale Sardar section, Shotori Range by Yazdi and Turner (2000), which helped to improve understanding of linkages between western and eastern Gondwana but were not useful in terms of a detailed biostratigraphy.

In Eastern Iran, the Nias section $\left(33^{\circ} 39.512^{\prime} \mathrm{N}, 57^{\circ}\right.$ 08.568' E) (Yazdi 1999; Wendt et al. 1997, 2005) seems to represent a relatively undisturbed section probably including the D-C boundary. Frasnian and Famennian sediments including the Annulata Event are reported by several authors from that section (Feist et al. 1999; Morzadec 2002; Becker et al. 2004). Wendt et al. (2005) determined conodonts from the last carbonate layer of this section (but conodonts were not figured) which may indicate a middle Tournaisian age, but the D$\mathrm{C}$ boundary was not yet constrained and future investigations are necessary. More sections were studied such as a section near Tabas (section A, 2 km NW from Tang-e-Abbassi; see Yazdi 1999), but the D-C boundary interval is characterised by a sedimentological hiatus/erosional surface. Thus, in the Shotori Range, the sections published by Bahrami et al. (2011) are the best D-C sections known so far even if hiatuses may occur. Thus, a more detailed stratigraphic framework is necessary, as well as a more detailed sedimentological record, and a systematic record of other fossil groups, and the study of geochemical proxies in order to get a better understanding for trigger mechanisms of the ecological collapse of the Hangenberg Crisis in shallow-water palaeoenvironments.

\section{Alborz Mountains}

The range of Alborz Mountains is $60-130 \mathrm{~km}$ wide and extends from NW Iran (East Azerbaijan Province) along the Caspian Depression into the Kope-Dagh and northwestern Afghanistan. In the Kope-Dagh, which was part of Laurussia (Berberian and King 1981), Palaeozoic rocks occur in remote settings close to the Turkish-Afghan border, and two sections were described by Wendt et al. (2005). The sedimentological record considerably differs from that of the other sections in Iran, and whether the successions contain Carboniferous rocks remains questionable.

Mid-Palaeozoic rocks in the central part of the Alborz Mountains are known for a long time (e.g. Wendt et al. 2005, cum lit.). Rocks are characterised by platform-type sediments, such as limestones, dolostones, sandstones and shales. Some sections exhibit more hemipelagic successions, but also hiatuses and unconformities obviously occur in Palaeozoic rocks in the central Alborz Mountains. Devonian and Carboniferous deposits in eastern Alborz are much thicker and more fossiliferous than the deposits of central and western Alborz and thus has become of special interest to study D-C boundary sections (e.g. Weddige 1984; Wendt et al. 2005; Habibi et al. 2008; Mohammadi 2009). Whereas the Upper Devonian Jeirud Formation (Assereto 1963) generally is composed of intratidal to supratidal sediments, the Lower Carboniferous Mobarak Formation (Stepanov 1971) exhibits the most extensive carbonate cycle along the northern margin of Gondwana (Torsvik and Cocks 2004; Wendt et al. 2005).

The sedimentological record of the type section of the Jeirud Formation (e.g. Gaetani 1965; Djafarian 1973; Wendt et al. 2005) is not useful to define the D-C boundary as the top 

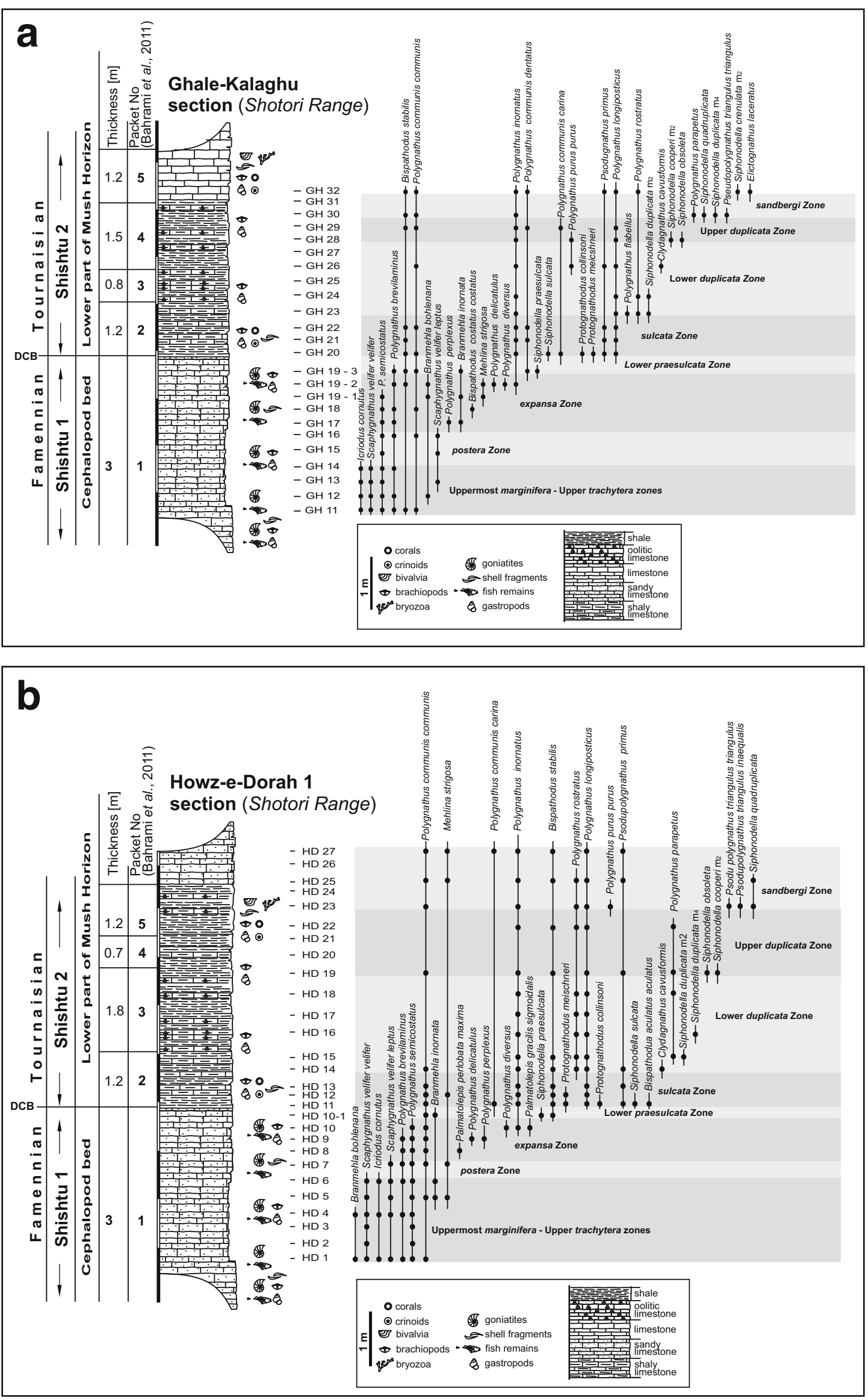
Fig. 2 a Lithology, sample position and conodont biozonation around the D-C boundary of the Ghale-Kalaghu section (modified after Bahrami et al. 2011). b Lithology, sample position and conodont biozonation around the D-C boundary of the Howz-e-Dorah 1 section (modified after Bahrami et al. 2011). c Lithology, sample position and conodont biozonation around the D-C boundary of the Howz-e-Dorah 2 section (modified after Bahrami et al. 2011)

of the Upper Famennian is covered by a 300-m-thick basalt flow (Sartenaer 1964; Gaetani 1965). The type section of the Mobarak Formation investigated by Assereto (1963) requires much more detailed sedimentological as well as stratigraphical studies. Furthermore, the underlying Jeirud Formation is strongly faulted.

In the central Alborz Mountains, the Shahmirzad section (base of the section $35^{\circ} 47.29^{\prime} \mathrm{N}, 53^{\circ} 18.84^{\prime}$ E; Fig. 3) is the best studied section in that region. The several-hundredmeter-thick Jeirud Formation which unconformably lies upon the upper part of the Mila Formation (Ordovician) (Peng et al. 1999; Wendt et al. 2005) is mainly composed of greenish and reddish shales, quartzites, reddish sandstones, dolomitic and conglomeratic sandstones and sandy limestones which point to a fluvial-deltaic palaeoenvironment with intervals of fully marine sediments (Ueno et al. 1997). Based on rare fossils, this formation has a stratigraphic range from Mid-Devonian to Lower Carboniferous (e.g. Gaetani 1965; Kimyai 1972; Ghavidel-Syooki 1995). The Jeirud Formation is continuously overlain by the Mobarak Formation which is represented by fossiliferous limestones, black shales and marly limestones, suggesting a subtidal palaeoenvironment. The Carboniferous part of the Shahmirzad section contains a number of different fossil groups such as crinoids, brachiopods, bryozoans and gastropods (Ueno et al. 1997; Webster et al. 2007). The most detailed stratigraphy based on conodonts was published by Habibi et al. (2008) (see Fig. 3).

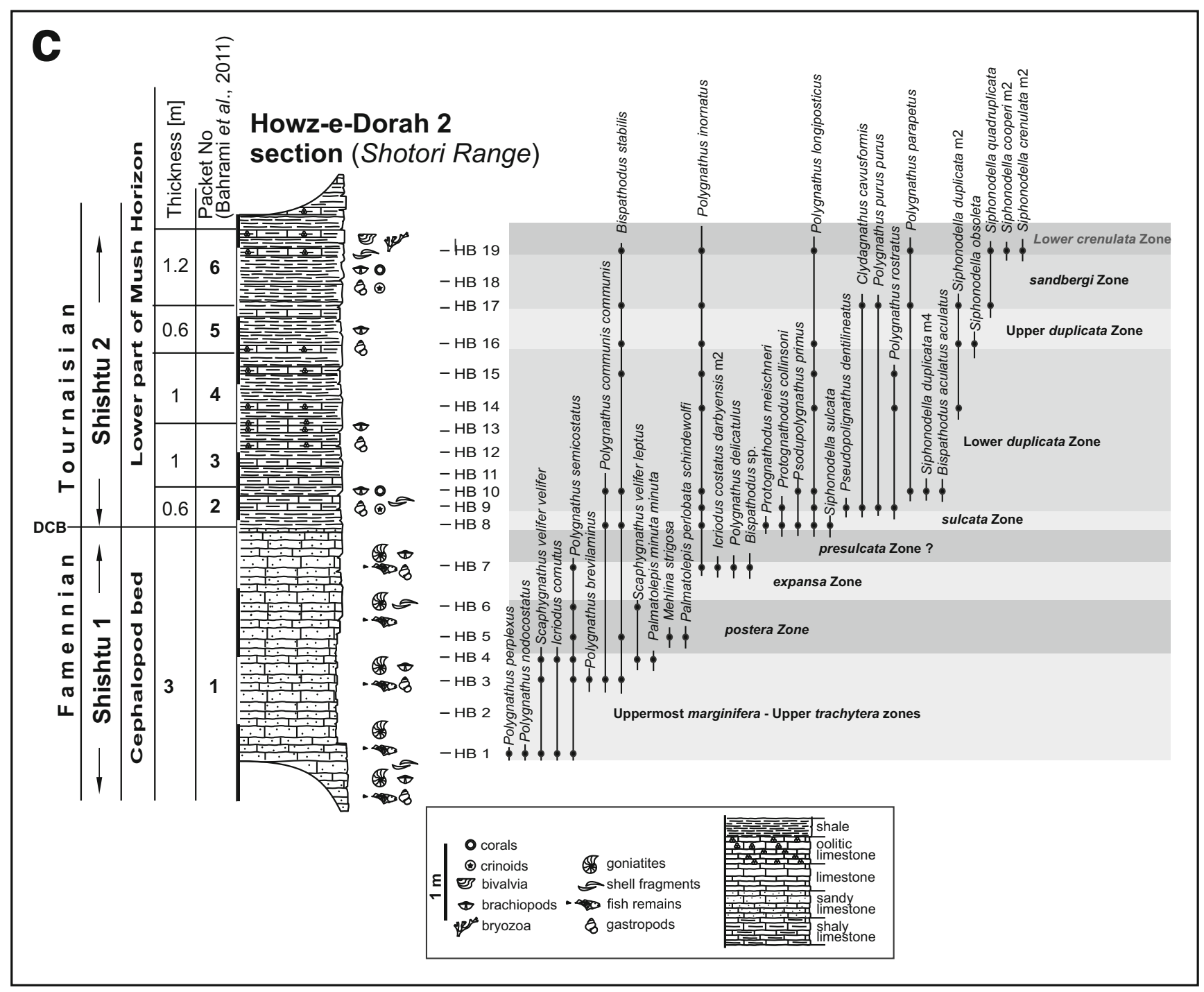

Fig. 2 (continued) 
Fig. 3 Lithology, sample position and conodont biozonation around the D-C boundary of the

Shahmirzad section (modified after Habibi et al. 2008).

Siphonodella sulcata M4 was found in sample 16




Due to the palaeoenvironmental setting, the conodont fauna is quite scarce and not well preserved. Nevertheless, these authors discriminated six conodont zones and the D-C boundary which is defined by the first occurrence of Siphonodella sulcata in sample 16 (Fig. 3). The disadvantage of this section is based on the very shallow-water sediments of the Jeirud Formation. Thus, a very limited number of conodonts were found in the uppermost part of the succession (uppermost Famennian), and most conodonts were described from the overlying Carboniferous Mobarak Formation. On the other hand, the occurrence of a rich acritarch association and the rare conodont findings allow to place the D-C boundary below sample number 16 (Habibi et al. 2008). The spore Retispora lepidophyta was found in sample P2 in this section. According to Streel and Loboziak (1996, p. 582), Retispora lepidophyta has his first occurrence within the Late expansa Zone (ultimus Zone of Spalletta et al. 2017) and became extinct just below the D-C boundary, while the other taxa have a longer range. The first occurrence (FO) of Protognathodus kockeli in this section cannot be used for conodont zonation and cannot be applied to determine the kockeli Zone as this species was found after Habibi et al. (2008) for the first time which was much higher in the section (sample 30, L. typicus-anchoralis-latus interval). Therefore, the new proposed zonation by Spalletta et al. (2017) is not helpful here since the DCB interval would remain undivided by conodonts. Since Protognathodus kockeli is not known from the typicus-anchoralis-latus Zone but became extinct already in the crenulata Zone after the current state of knowledge, a re-evaluation of ranges in different environmental settings is necessary. Also, confusion with the homeomorphic Gnathodus fauna which occurs in the typicus-anchoralis-latus Zone could be one possible reason (Kaiser and Hubmann in prep.).

In the light of ongoing discussions, three sections in the Alborz Mountains are under study by an Iranian/German working group. These sections have a potential to increase knowledge on the Late Devonian biodiversity crises in different neritic palaeoenvironments and the Hangenberg Biocrisis in particular. The state of knowledge at the time of this writing is given for the three sections.

The Mighan section is located about $22 \mathrm{~km}$ northeast of Shahroud City ( $36^{\circ} 38^{\prime} 38.2^{\prime \prime}$ N, 54 $56^{\circ} 55.8^{\prime \prime}$ E; Fig. 4) and was described by many authors (e.g. Jenny 1977; Karimi 2001; Wendt et al. 2005). The section has a stratigraphic range

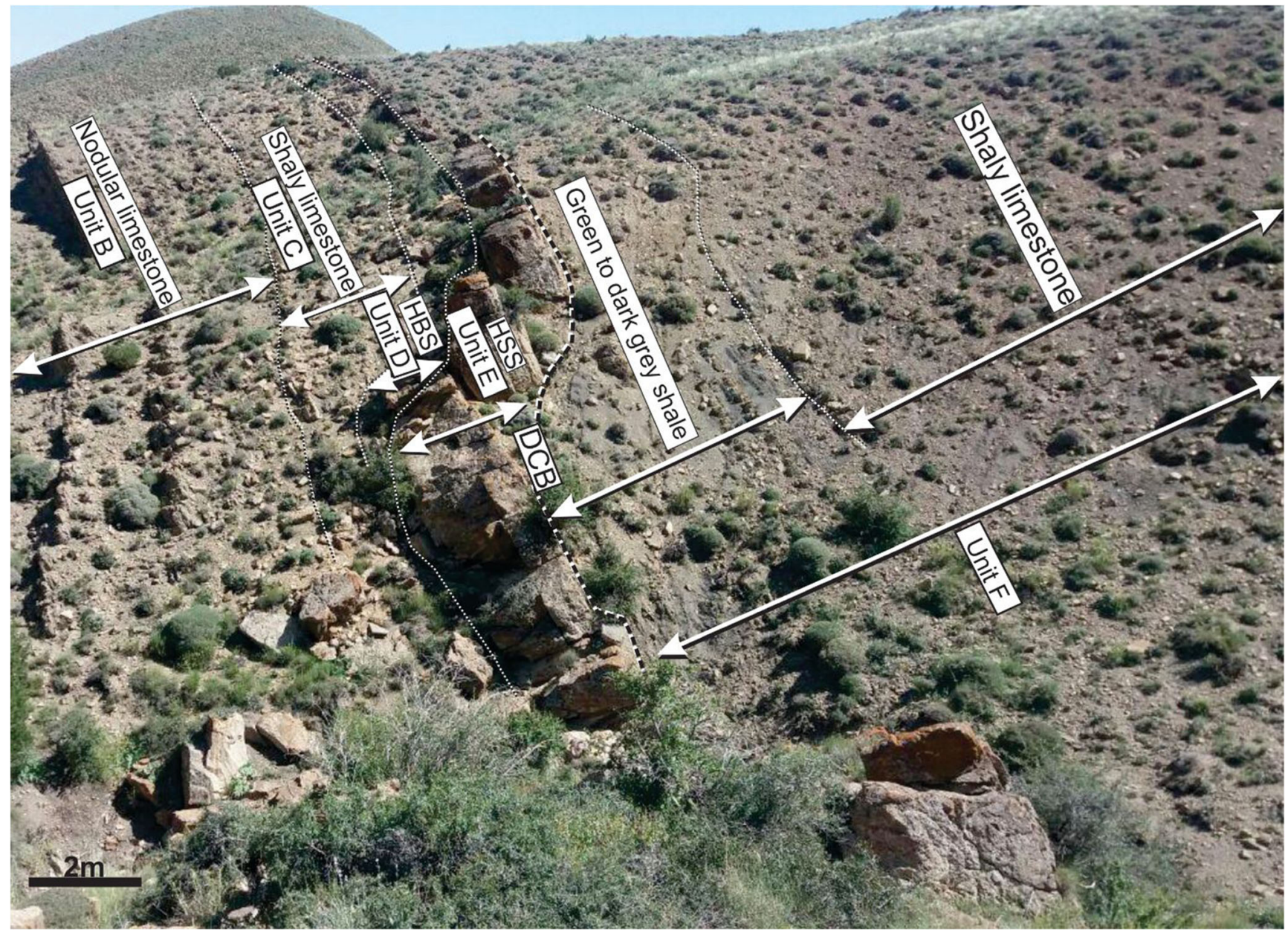

Fig. 4 Mighan section in the Alborz Mountains. Detail of the sampled interval across the D-C transition 
from (?) Silurian to Permian (Wendt et al. 2005). This succession includes uppermost sediments of the Devonian Khoshyeilagh Formation (74.35 m thick) and the lowermost Carboniferous Mobarak Formation (16.65 m thick). It is subdivided from base to top into six lithological units (units A to F; Fig. 5).

- Unit A (34.32 m thick) starts with 3-m alternation of grey to dark medium-bedded limestones and shales with trilobites, brachiopods, corals, gastropods and crinoids. It is followed by 10.20 -m-thick succession of green to grey marls with rare fossils. The marls are overlain by an alternation (5.32 m thick) of grey medium-bedded limestones and marls showing the same fauna as at the base of unit A. The topmost part of unit A is composed of green to grey marls which have a thickness of $18.80 \mathrm{~m}$.

- Unit B has a thickness of $30.4 \mathrm{~m}$ and is characterised by more calcareous sediments compared to the previous unit. The medium-bedded limestones exhibit a nodular fabric, and occasionally, they are bioturbated.

- Unit $\mathrm{C}$ which is $3 \mathrm{~m}$ thick contains grey medium-bedded marly limestones. Rare macrofossils such as trilobites occur. This unit contains the conodont Siphonodella praesulcata and is conformably overlain by grey shales.

- Unit D is composed of mainly grey shales with rare brachiopods and trilobites and has a thickness of $1.25 \mathrm{~m}$. This succession is most probably the equivalent of the HBS.

- Unit E (2.5 m thick) contains mainly white cross-bedded sandstones (in distinct layers, also reddish sandstones occur) with some shell fragments and crinoids representing a shallow-neritic palaeoenvironment. The sandstones of unit $\mathrm{E}$ can be considered as an equivalent of the HSS.

- Unit $\mathrm{F}$ has a thickness of $16.53 \mathrm{~m}$ and starts with 30-cm-thick grey medium-bedded limestones which yielded Siphonodella sulcata. This Lower Carboniferous limestone is overlain by $5.23-\mathrm{m}$ green and dark grey shales following upwards to grey medium-bedded shaly limestones ( $11 \mathrm{~m}$ thick). In the uppermost part of this unit, an increase of bioclasts such as brachiopods, gastropods, ostracods, crinoid stems and corals occurs. A general sedimentological change from sandstones in unit $\mathrm{E}$ to carbonates in unit $\mathrm{F}$ indicates more distal palaeo-environments.

The investigated part of the Mighan section ranges stratigraphically from the Bispathodus aculeatus aculeatus conodont Zone (Spalletta et al. 2017) to the Siphonodella sulcata/Protognathodus kuehni (Kaiser et al. 2009) conodont Zone (Fig. 5, Table 1). Herein, we present an overview on conodonts found in the section, and more details will be published by Parvizi et al. (in prep.) as a part of Parvizi's PhD thesis. As this research is work in progress, data on other fauna, a detailed sedimentology/facies description and geochemical data will be published later.

Unfortunately, most conodont samples of the Mighan section were barren, and only 28 samples out of about 45 yielded conodont elements. The abundance is quite scarce with few elements/kg only, except sample M26 which yielded 41 elements $/ \mathrm{kg}$ (Table 1), and the preservation of conodont elements is not good, since many specimens are broken and incomplete. We discriminated 23 species and subspecies which belong to 4 genera (Bispathodus, Polygnathus, Pseudopolygnathus, Siphonodella). The genus Bispathodus is, by far, the most abundant, representing $25.7 \%$ of the entire fauna. Due to facies setting (most conodonts are broken), we counted $62 \%$ of unassigned conodont elements.

The disadvantage of conodont samples in that section is the lack of significant conodonts such as Protognathodus kockeli and $P$. kuehni; the former one was used for the new conodont biozonation (Spalletta et al. 2017) as marker species, and $P$. kuehni can be considered as a reliable index fossil for the sulcata Zone (see Kaiser et al. 2019, cum lit.). However, we found two specimens of Siphonodella praesulcata (samples M32 and M36) and one specimen of Siphonodella sulcata (sample M36) instead. Thus, it is possible to define the D-C boundary in this section based on the presently valid biostratigraphic criteria. Whether the combined biostratigraphic, sedimentological and future geochemical set of criteria confirms the position of the boundary depends on current research. Preliminary sedimentological criteria support the suggested position of the D-C boundary in the Mighan section as shown in Fig. 5.

The Chelcheli section (base of the section $36^{\circ} 36^{\prime}$ $\left.15.54^{\prime \prime} \mathrm{N}, 54^{\circ} 32^{\prime} 55.57^{\prime \prime} \mathrm{E}\right)$ is also characterised by shallow-water facies. In distinct layers, limestones and shales exhibit diverse fauna which is composed of corals, bryozoans, vertebrate remains, brachiopods and gastropods among others. Work in progress concerns a detailed description of the fauna, sedimentology and the study of geochemical proxies. Herein, we present a preliminary record on conodont occurrences of this section (Fig. 6). It is noteworthy that specimens of Protognathodus are not completely absent and obviously co-occur with the early but rare siphonodellids. However, the Protognathodus and Siphonodella records from Iran have to be confirmed in more detailed taxonomic studies. In this respect, the specimens of Protognathodus are represented by morphotypes which can be regarded as atypical morphotypes (GhaleKalaghu section and Howz-e-Dorah section (Bahrami et al. 2011), Plate 4, Figs. 14-17, and unpublished faunal record from Chelcheli) due to their affinity to the homeomorphic Gnathodus faunas.

The D-C transition of the Khoshyeilagh section (base of the section $36^{\circ} 55^{\prime} 11.03^{\prime \prime} \mathrm{N}, 55^{\circ} 26^{\prime} 53.95^{\prime \prime} \mathrm{E}$ ) is also part of our 


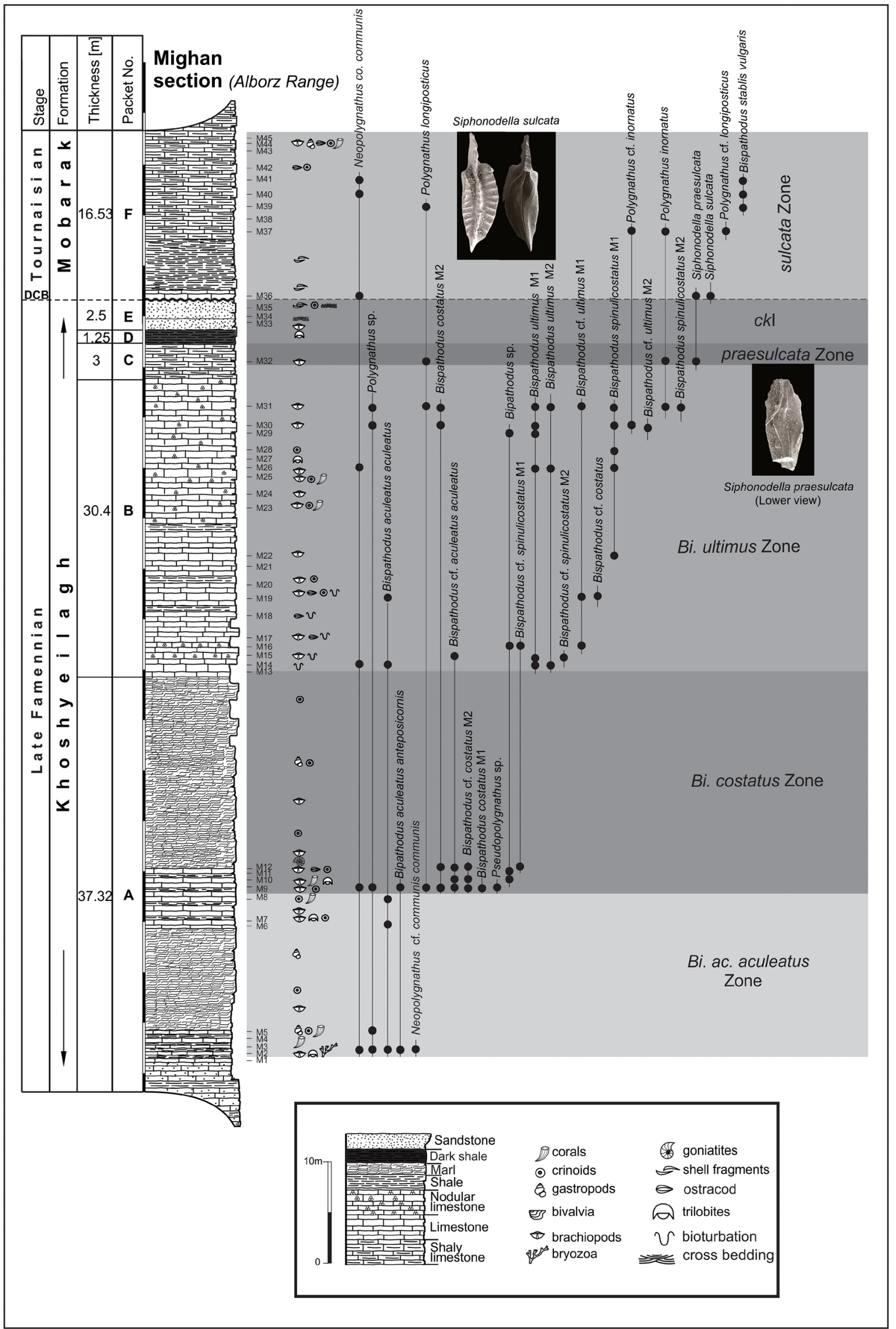

Fig. 5 Lithology, sample position and conodont distribution of the Mighan section. Siphonodella sulcata M4 was found in sample M36 


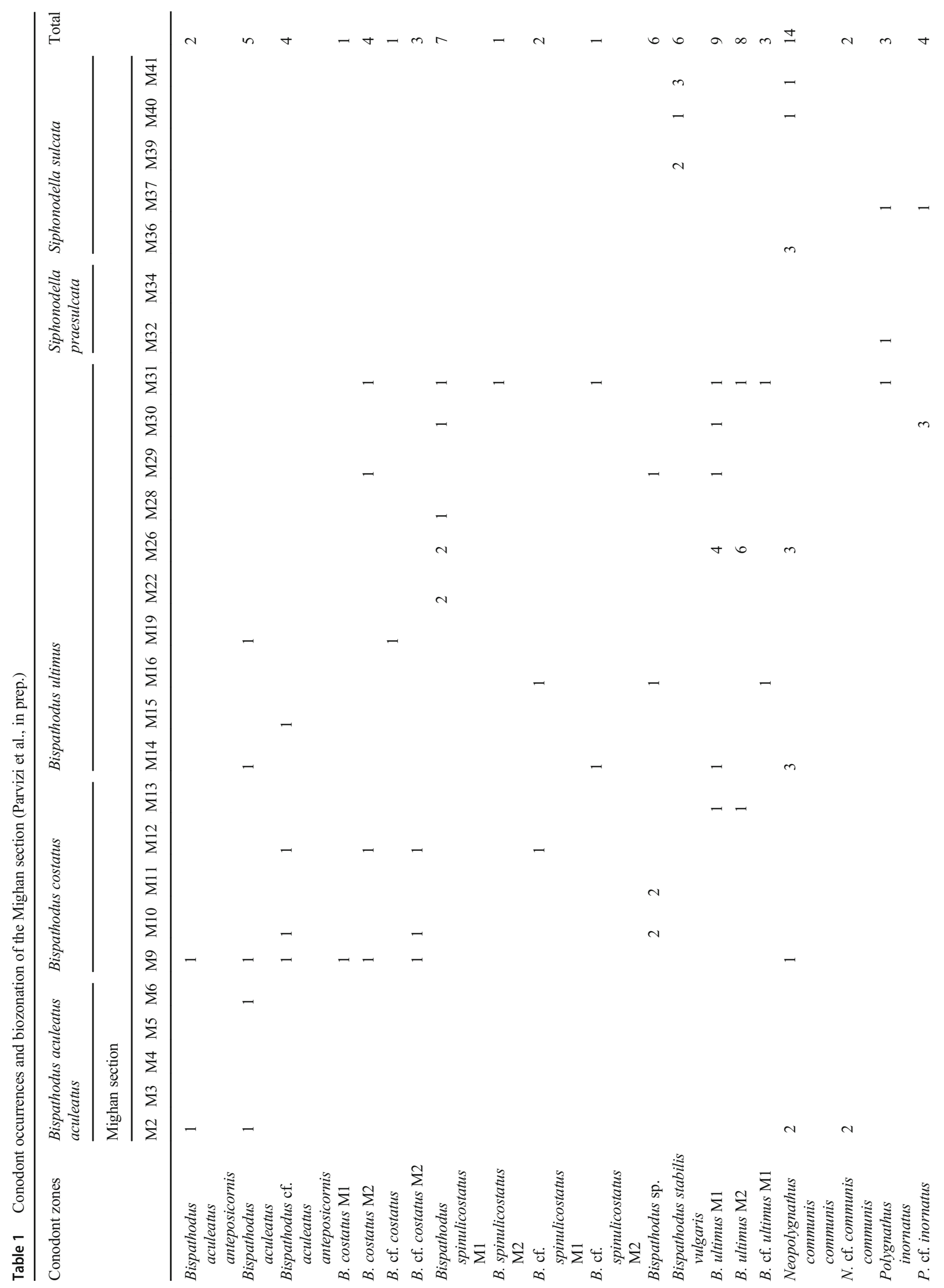




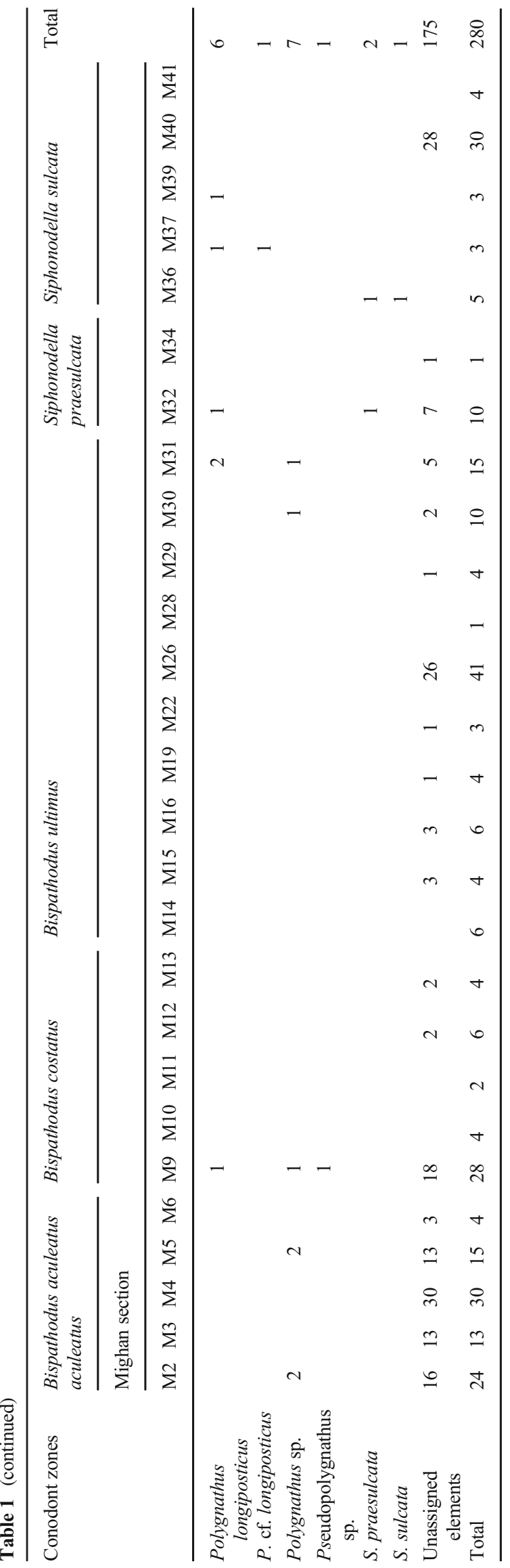

joint research project. The entire section has a thickness of about $1300 \mathrm{~m}$ and was first described by Bozorgnia (1973). Several workers studied this section, focussing on different fossil groups (e.g. Brice et al. 1974, 1978; Ahmadzadeh Heravi, 1971; Blieck et al. 1980; Hamdi and Janvier 1981; Weddige 1984; Ghods 1982; Morzadec 2002; Wendt et al. 2005). Sediments around the $1.5-\mathrm{m}$-thick D-C transition are composed of an alternation of grey to black shales with hematitic nodules and siltstones with small brachiopods (? equivalent to the HBS) which are conformably overlain by sandstones and shales (? equivalent to the HSS). As conodont determination and microfacies analysis are not yet finished at the time of this writing, we present a preliminary overview of our study (Fig. 7).

The Jaban section ( $\left.35^{\circ} 39^{\prime} 34.57^{\prime \prime} \mathrm{N}, 52^{\circ} 15^{\prime} 3.36^{\prime \prime} \mathrm{E}\right)$ in the central Alborz Mountains was described recently by Sardar Abadi et al. (2015). Lower Carboniferous sediments (Mobarak Formation) conformably overlie siliciclastic Late Devonian (Geirud Formation) successions, but the authors of that report have had a focus on Lower Carboniferous rocks and older sediments were not described. Thus, there is no detailed information whether this section contains equivalent rocks representing the Hangenberg Biocrisis. Moreover, the early Tournaisian interval is characterised by a hiatus, so that the D-C boundary cannot be determined (Sardar Abadi et al. 2015). Several other fossiliferous sections in the eastern Alborz were repeatedly investigated in the last decades (e.g. Blieck et al. 1980; Weddige 1984; Ashouri 1990; Wendt et al. 2005 ) such as the Deh Molla section ( $36^{\circ} 38^{\prime} 38.2^{\prime \prime} \mathrm{N}, 54^{\circ} 56^{\prime}$ $55.8^{\prime \prime}$ E) (see Wendt et al. 2005), but this section exhibits a considerable reduction in thickness and shows an incomplete succession and thus it is not useful to study the D-C transition. Another section in central Alborz was studied by Falahatgar et al. (2015). Their study focused on Tournaisian foraminifers. The Tournaisian seems to be complete and continuous which allows the discrimination of MFZ1 to MFZ8 biozones, but the disadvantage is that the base of the Kahanag section is only characterised lithostratigraphically (Falahatgar et al. 2015).

Central Iran

One of the most fossiliferous $\mathrm{D}-\mathrm{C}$ sections ranging from the Late Devonian to the Carboniferous (Late Mississippian) in Central Iran is the Anarak 1 section (base of the section $33^{\circ}$ $11.327^{\prime}$ N, $53^{\circ} 53.655^{\prime}$ E) (see Reyer and Mohafez 1970; Sharkovski et al. 1984; Wendt et al. 2005), but close to the D-C boundary, this section exhibits minor faults and a major gap which comprises almost the entire Famennian and the Tournaisian (Wendt et al. 2005).

Late Devonian conodonts (Siphonodella praesulcata Zone sensu Kaiser et al. (2009), Shishtu Formation) from the Dalmeh section were described by Hairapetian and Yazdi (2003). Younger sediments are not reported, and the conodont 


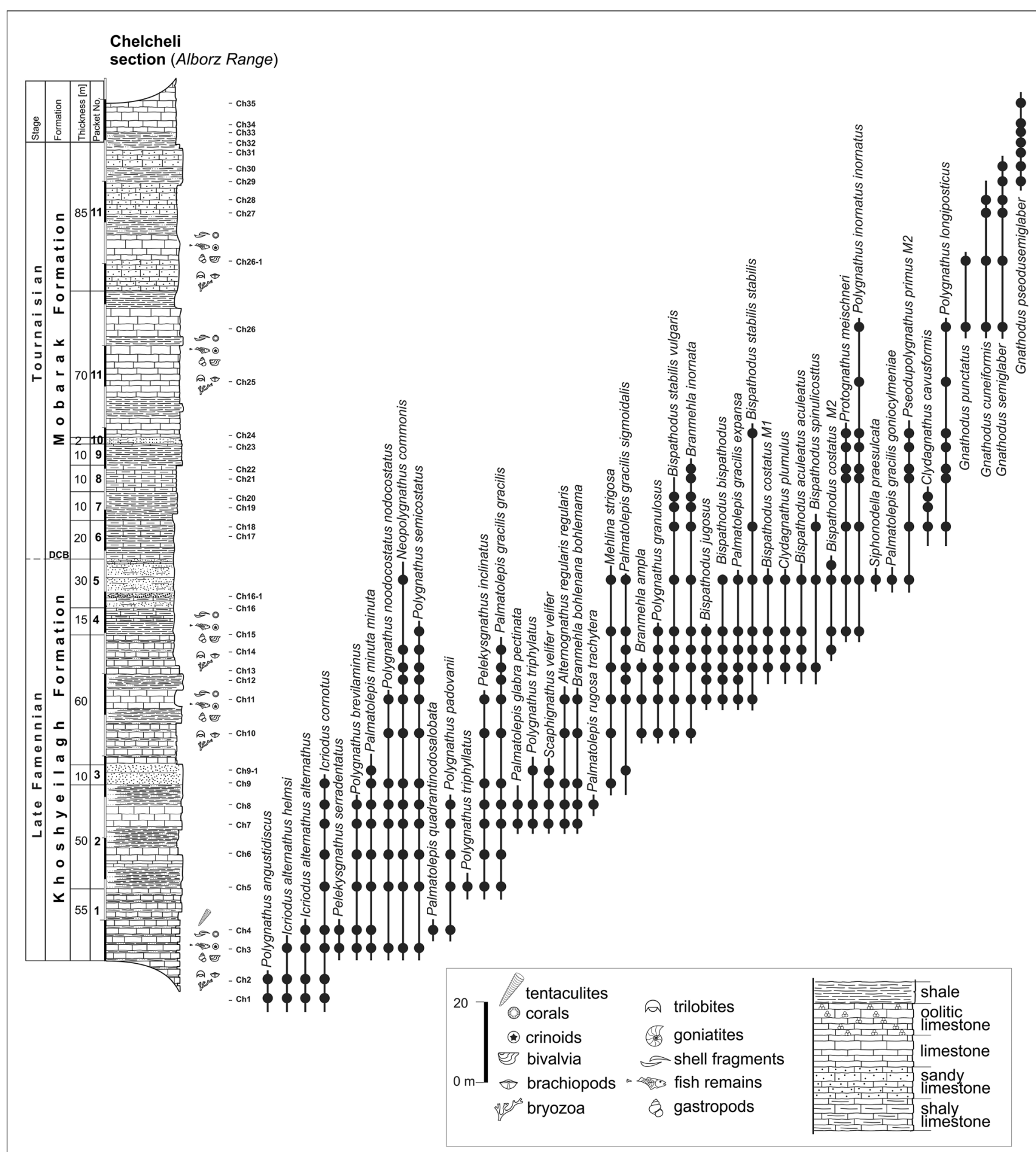

Fig. 6 Lithology and preliminary conodont distribution of the Chelcheli section of the Alborz Mountains. The D-C is not well defined, but it is most probably to be placed at the lower part of package 6

fauna is mainly composed of shallow-water species such as Icriodus forms. Youngest sediments of this section are composed of massive oolitic limestones. Hairapetian et al. (2000) mentioned late Famennian vertebrate remains from this section, but an overview on the entire faunal elements is not documented. The same section was sampled by Wendt et al.
(2005), but they did not find conodonts neither in the well-bedded, laminated limestones and shales of the Bahram Formation nor in the Lower Carboniferous dolostones (Hutk Formation). The sediments were obviously slightly metamorphosed, and thus, conodont samples from the base to the top were barren. Correlation with the Kuh-e-Bashi section which 
Fig. 7 Lithology and preliminary conodont record of the Khoshyeilagh section

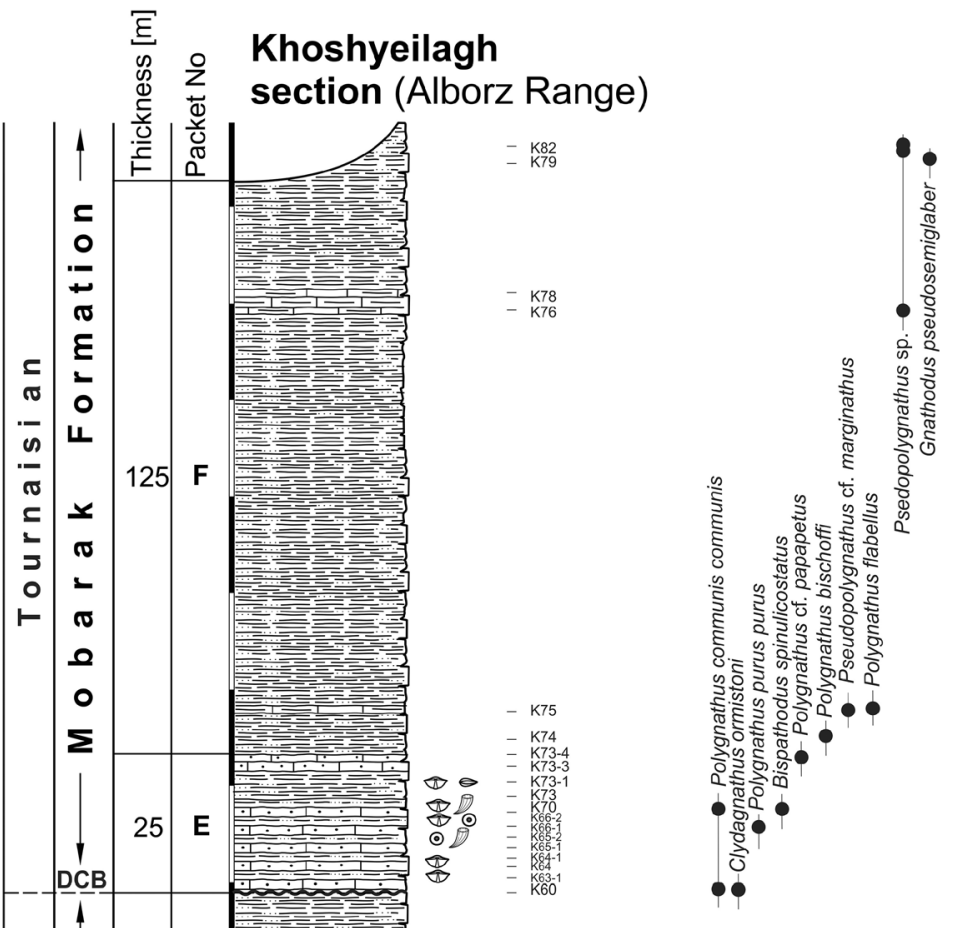

K59-2

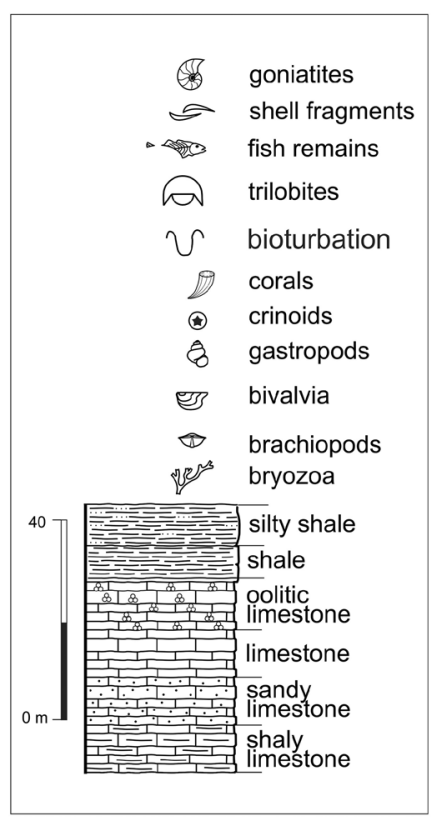


is located approximately $25 \mathrm{~km}$ to the southeast is mainly based on lithology. The Lower Carboniferous rocks of this section are composed of dolostones whose age is still unclear (Wendt et al. 2005). Due to the biostratigraphic uncertainties and not suitable facies, more detailed studies on the D-C boundary in both sections are not worthwhile.

Another two D-C sections (Rahdar and Bakshi sections) further to the east are exposed in the Rahdar-Gachal Anticline (Wendt et al. 2005), in the "Kashmar-Kerman Tectonic Zone" (Ramezani and Tucker 2003) west of the Kalmard Fault exhibiting reduced Late Devonian and more complete Early Carboniferous successions. According to Wendt et al. (2005), the conodont fauna is scarce in Devonian as well as in Carboniferous sediments as a result of very shallow-water palaeoenvironments. Thus, in both sections, it seems unlikely to define the D-C boundary.

\section{Concluding remarks}

A great number of D-C sections were described in Iran in the last decades and improved the knowledge on stratigraphy, facies and palaeoenvironmental setting. But in many cases, the focus of those studies was either on a specific fossil group or stratigraphy. Some reports and theses are only partly accessible, and conodont assemblages (as well as other fauna) reported in various publications have not been figured and/or are not accessible anymore. Thus, a more comprehensive methodological approach of promising D-C sections is necessary.

We summarise and describe most suitable D-C sections in Iran (Fig. 8) and present the state of knowledge on re-sampled sections in the Alborz Mountains. Most sections contain small hiatuses around the D-C transition as shown above or in the publication by Bahrami et al. (2011) as a result of the overall shallow-water facies, but some sections may contain a more or less complete succession as it is the case in the Mighan section (Parvizi et al., in prep.).

Based on the state of knowledge, no D-C sections in Iran investigated so far seem to be a GSSP candidate due to the overall facies setting and thus often incomplete sedimentologic and biostratigraphic record. But, some sections provide a number of new results on the Hangenberg Biocrisis in shallowwater facies with respect to conodont stratigraphy, faunal assemblage, sedimentology/facies and geochemistry. As shown in this paper, some Iranian successions could have a high correlative potential with neritic successions in Europe, Morocco or China (e.g. Kaiser et al. 2004; Brice et al. 2007; Qie et al. 2015) due to the co-occurrence of biostratigraphic significant pelagic/hemipelagic (conodonts) and neritic (ostracods, brachiopods, corals, trilobites, gastropods, etc.) organisms.

Whether the sections under study (Chelcheli, Mighan and Khoshyeilagh) presented herein are characterised by small hiatuses at the D-C transition has to be proven by further detailed research. The assumption of a gap at the D-C boundary, above the regressive HSS, is based mainly on the absence of P. kockeli and P. kuehni faunas (Bahrami et al. 2011). However, it has to be considered that event-related, often highly condensed successions resulted in missing occurrences, or in diachronous first occurrences of fossils, especially of the facies-dependent early siphonodellids and early protognathodids (Kaiser et al. 2019). Therefore, the delayed entry or even absence of marker fossils as a consequence of major environmental changes during the Hangenberg Biocrisis at the D-C boundary, which is widely known from many other regions, could probably also applied for the Iranian shallow-water successions. This assumption is supported by the lithofacies. For example at Chelcheli, the carbonate sediments lying conformably above the HSS, and a sedimentological hiatus above the HSS, seem unlikely. Moreover, the Mighan section seems to represent a continuous succession around the D-C boundary, too.

The Protognathodus fauna in Iran is represented by Protognathodus meischneri and Protognathodus collinsoni previously reported by Bahrami et al. (2011), while the biostratigraphic significant $P$. kockeli (index marker for the kockeli Zone after Kaiser et al. (2009) = Upper praesulcata Zone) and P. kuehni (index marker for the joint sulcatalkuehni Zone after Kaiser et al. (2009) = sulcata Zone) faunas were not reported (except in the late Tournaisian by Habibi et al. 2008). However, more high-resolution biostratigraphic studies are needed in order to evaluate the occurrence of the early protognathodids. The absence of marker conodonts could be related to gaps, or facies-dependent late or rare occurrences, as explained above. Although condensation of event beds is less likely because of the overall micritic facies in the studied regions, it should be considered as well since the DCB interval is globally characterised by a carbonate crisis due to a glaciation pulse (Kaiser et al. 2008). Thus, the absence of marker conodonts due to condensation is, in this case, caused by previous sampling biases.

The praesulcata Zone, the extinction-based costatuskockeli Interregnum (HBS and HSS) of Kaiser et al. (2009) and the sulcata Zone can be recognised in the recently investigated Iranian successions as shown in the Mighan section (Fig. 5), while the kockeli Zone as well as the bransoni (duplicata) Zone cannot be recognised by conodonts. Since the biozonation concept of Spalletta et al. (2017) does not consider the praesulcata and sulcata zones as well as the $c k \mathrm{I}$, the Iranian successions could consequently not been subdivided by conodonts at the D-C transition by applying this biozonation concept.

Based on the well-known morphological complexity of marker conodonts at the D-C boundary, especially of the siphonodellids, polygnathids and Siphonodella-like siphonodellids (Kaiser and Corradini 2011; Becker et al. 2013), the Iranian successions can provide new important data 


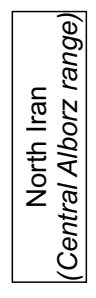

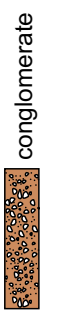

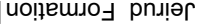
।
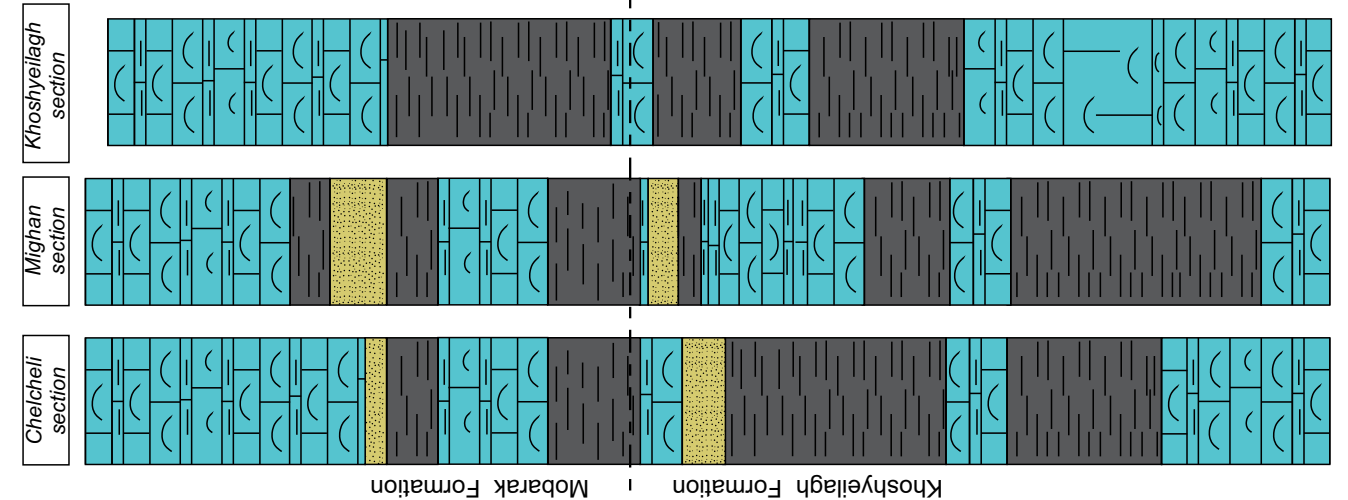

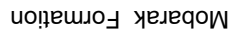

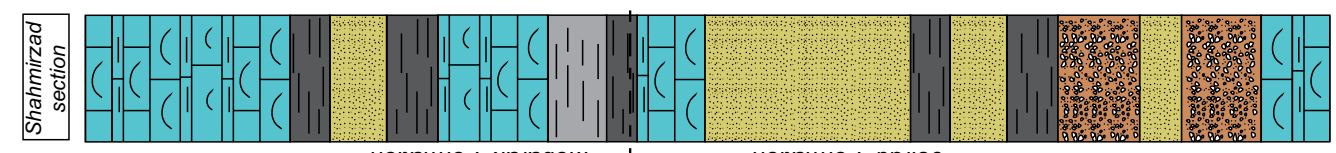

иo!̣emı」 уелеqоW
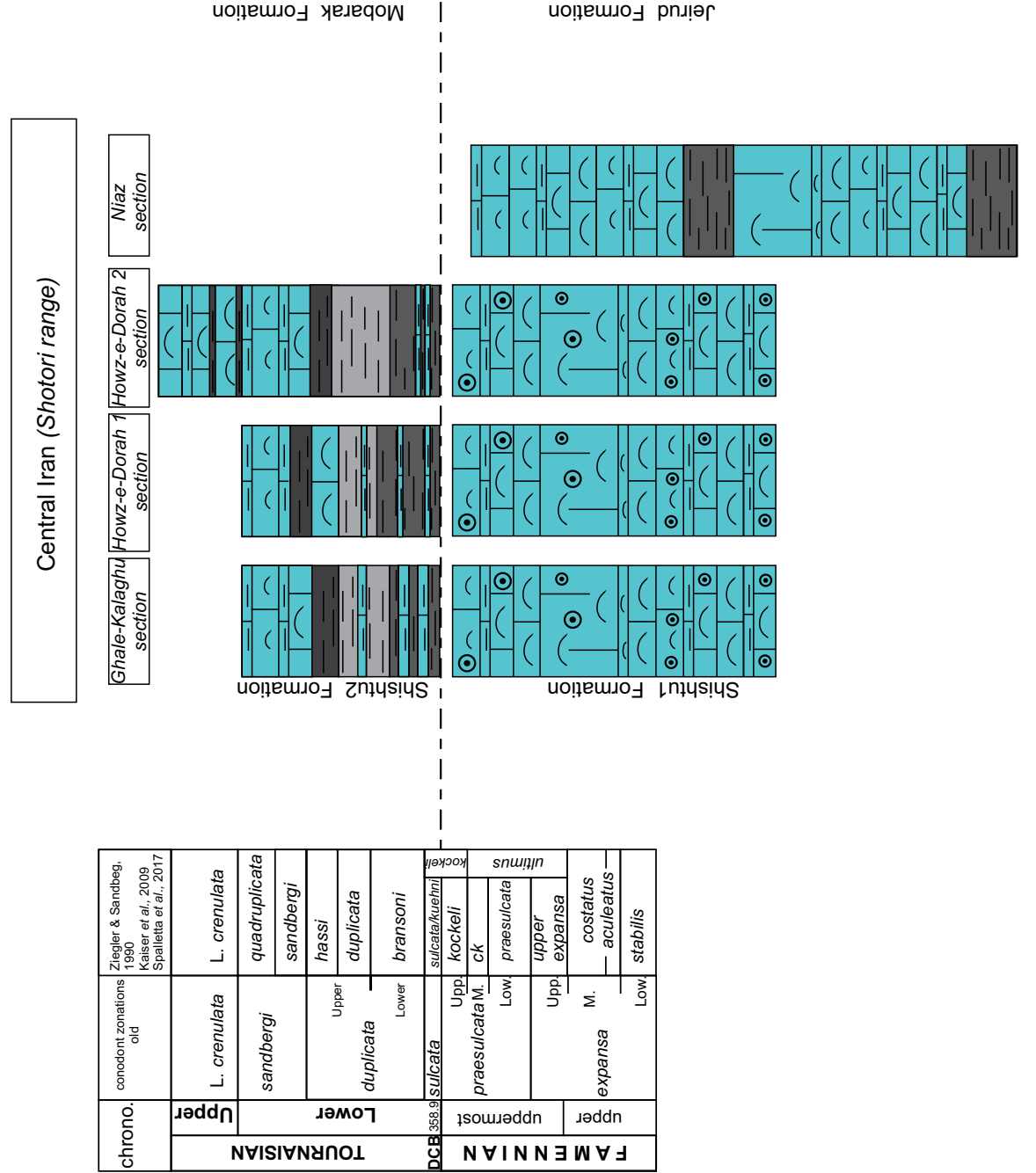

협 흏

政

के

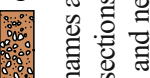

$\because$ 그응

总递官

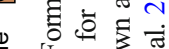

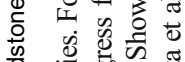

듀

点言 कौ

을

范宽

不范

要震

8 원

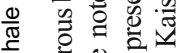

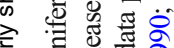

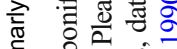

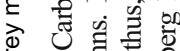

||

证

व 4 के

要运

o क त

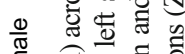

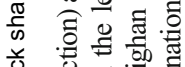

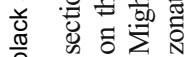

11

䒕 导

․․류

응

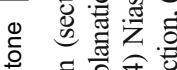

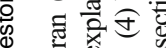

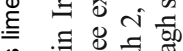

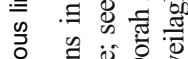

这

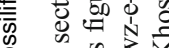

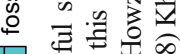

1)

(1) 듕

(

岁造总

ه

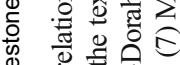

密

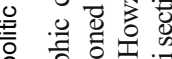

련를

줃

क

0 . 음 융

( )

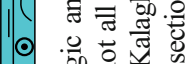

응 웜

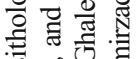

俅焉

$\infty$.

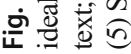


on conodont biostratigraphy. Thus, further detailed conodont studies are required to be supported by other methodologies (e.g. geochemistry, facies, magnetic susceptibility among others) to clearly define the D-C boundary in different facies. Nevertheless, research in shallow-water facies such as in Iran will help to reduce serious palaeoenvironmental and palaeogeographic sampling bias which may limit our knowledge on events in general, and particularly on one of the most severe extinction events in Earth's history.

Finally, a specific problem in Iran arises with the given formation names of the described sections. Depending on the study areas, different formation names occur for the same time slice even if the lithological record is similar. A much better sedimentological record combined with a more precise stratigraphic range of some formations is necessary (as it was shown by Bahrami et al. (2018) for the Bahram Formation) in order to provide a better correlation between different sections in different tectonic settings or areas in Iran.

Acknowledgements The authors acknowledge the constructive reviews by Tomas Kumpan (Brno, Czech Republic) and Markus Aretz (Toulouse, France). The authors are grateful to the University of Isfahan for providing the technical support. This is a contribution to IGCP Project 652 (Reading geologic time in Palaeozoic rocks: the need for an integrated stratigraphy).

Funding Open Access funding provided by Projekt DEAL. One of the authors (P.K.) acknowledges funding by Deutsche Forschungsgemeinschaft (DFG; KO 1622/16-1). This study also received financial support from the University of Isfahan.

\section{Compliance with ethical standards}

Conflict of interest The authors declare that they have no conflict of interest.

Open Access This article is licensed under a Creative Commons Attribution 4.0 International License, which permits use, sharing, adaptation, distribution and reproduction in any medium or format, as long as you give appropriate credit to the original author(s) and the source, provide a link to the Creative Commons licence, and indicate if changes were made. The images or other third party material in this article are included in the article's Creative Commons licence, unless indicated otherwise in a credit line to the material. If material is not included in the article's Creative Commons licence and your intended use is not permitted by statutory regulation or exceeds the permitted use, you will need to obtain permission directly from the copyright holder. To view a copy of this licence, visit http://creativecommons.org/licenses/by/4.0/.

\section{References}

Ahmadzadeh Heravi, M. (1971). Stratigraphische und paläontologische Untersuchungen im Unterkarbon des zentralen Elburs (Iran). Clausthaler Geologische Abhandlungen, 7, 1-114.

Alavi, M. (1991). Sedimentary and structural characteristics of the PaleoTethys remnants in northeastern Iran. Geological Society of America Bulletin, 103, 983-992.

Aretz, M. (2013). Report on the workshop of the task group for defining the Devonian-Carboniferous boundary. In M. Aretz, B. Richards, P. Kabanov, \& S. Nikolaeva (Eds.) Newsletter on Carboniferous stratigraphy (pp. 31-35). International Union of Geological Sciences, Subcommission on Carboniferous Stratigraphy.

Ashouri, A.R. (1990). Devonian and Carboniferous conodont faunas from Iran. PhD Thesis, University of Hull, $351 \mathrm{p}$.

Ashouri A.R. (1995). Conodonts and cephalopod bed and Devonian/ Carboniferous boundary in Howz-e-Dorah. $14^{\text {th }}$ Symposium of Geosciences. Tehran, 68-71. [in Persian].

Ashouri, A. R. (1997a). Juvenile gastropods from the upper Devonian cephalopod beds and adjacent strata of Central Iran. Journal of Science, 8, 45-60 [in Persian].

Ashouri, A. R. (1997b). Revision of stratigraphical position of the "cephalopod beds" and Devonian-Carboniferous boundary and introducing 5 conodont zones in Howz-e-Dorah (East Iran). Geosciences, 6, 10-17 [in Persian].

Ashouri, A. R. (1998). The Devonian-Carboniferous boundary in Ozbak-Kuh area. Geosciences Scientific Quarterly Journal, 7, 47-53 [in Persian].

Ashouri, A. R. (2002). Palmatolepis (Conodonta; Late Devonian) from the Tabas region, East Iran. International Journal of Science, 3(2), $187-220$.

Ashouri, A. R. (2004). Late Devonian and Middle-Late Devonian conodonts from eastern and Northern Iran. Revista Española de Micropaleontología, 3, 355-365.

Ashouri, A. R. (2006). Middle Devonian-Early Carboniferous conodont faunas from the Khoshyeilagh Formation, Alborz Mountains, North Iran. Journal of Sciences, 17, 53-65 [in Persian].

Ashouri, A. R., \& Yamini, A. (2006). Cephalopods and stratigraphical position of cephalopod bed of Shishtu Formation, Iran. Geosciences Scientific Quarterly Journal, 15, 178-187.

Assereto, R. (1963). The Paleozoic formations in central Elburz (Iran) (preliminary note). Rivista Italiana di Paleontologia e Stratigrafia, 69, 503-543.

Bahrami, A., Corradini, C., Over, D. J., \& Yazdi, M. (2011). Upper Devonian-Lower Carboniferous conodont biostratigraphy in the Shotori Range, Tabas area, Central-East Iran microplate. Bollettino della Società Paleontologica Italiana, 50(1), 35-53.

Bahrami, A., Königshof, P., Boncheva, I., Yazdi, M., Khalaji, M. A. N., \& Zarei, E. (2018). Conodont biostratigraphy of the Kesheh and Dizlu sections, and the age range of the Bahram Formation in Central Iran. Palaeobiodiversity and Palaeoenvironments, 98(2), 315-329. https://doi.org/10.1007/s12549-017-0307-y.

Bai, S.-L. (2001). Ni-Ir anomaly, microtektites, and the biotic crisis across the Devonian-Carboniferous boundary, southern China. International Geology Review, 43(3), 265-275.

Bábek, O., Kumpan, T., Kalvoda, J., \& Grygar, T. M. (2016). Devonian/ Carboniferous boundary glacioeustatic fluctuations in a platform-tobasin direction: a geochemical approach of sequence stratigraphy in pelagic settings. Sedimentary Geology, 337, 81-99.

Becker, R. T., Ashouri, A. R., \& Yazdi, M. (2004). The Upper Devonian Annulata Event in the Shotori Range (Eastern Iran). Neues Jahrbuch fur Geologie und Paläontologie, Abhandlungen, 231, 119-143.

Becker, R.T., Hartenfels, S., Aboussalam, Z.S., Tragelehn, H., Brice, D. \& El Hassani, A. (2013). The Devonian-Carboniferous boundary at Lalla Mimouna (northern Maider) - a progress report. In R. T. Becker, A. El Hassani, A. Tahiri (Eds.), International field symposium "the Devonian and Carboniferous of northern Gondwana" - Morocco 2013. Documents de l'Institut Scientifique, Rabat 27, 109-120.

Becker, R.T., Kaiser, S.I. \& Aretz, M. (2016). Review of chrono-, lithoand biostratigraphy across the global Hangenberg Crisis and Devonian-Carboniferous Boundary. In R.T. Becker, A. El Hassani, \& A. Tahiri (Eds.) (2019). Devonian climate, sea level and evolutionary events. Geological Society, London, Special Publications, 423(1), 355-386. 
Berberian, F., \& King, G. C. P. (1981). Towards a paleogeography and tectonic evolution of Iran. Canadian Journal of Earth Science, 5, $101-117$.

Blieck, A., Golshani, F., Goujet, D., Hamedi, A., Janvier, P., Mark-Kurik, E. \& Martin, M. (1980). A new vertebrate locality in the Eifelian of the Kush-Yeilagh Formation, eastern Alborz, Iran. Palaeovertebrata, 9, Fasc. 5, 133-154.

Bozorgnia, F. (1973). Paleozoic foraminiferal biostratigraphy of central and east Alborz Mountains, Iran (Vol. 4, pp. 1-185). National Iranian Oil Company, Geological Laboratories.

Brezinski, D. K., Cecil, C. B., \& Skema, V. W. (2010). Late Devonian glacigenic and associated facies from the central Appalachian Basin, eastern United States. Geological Society of America Bulletin, 122(1-2), 265-281.

Brice, D., Jenny, J., Stampfli, G., \& Bigey, F. (1978). Le Devonien de l'Elbourz oriental: Stratigraphie, paleontologie (brachiopodes et bryozoaires), paleogeographie. Rivista Italiana di Paleontologia e Stratigrafia, 84, 1-56.

Brice, D., Lafuste, J., de Lapparant, A. F., Pillet, J., \& Yassini, I. (1974). Etude de deux gisements paleozoiques (Silurien et Devonien) de l'Elbourz oriental (Iran). Annales de la Societe Geologique du Nord, 93, 177-218.

Brice, D., Legrand-Blain, M., \& Nicollin, J.-P. (2007). Brachiopod faunal changes across the Devonian-Carboniferous boundary in NW Sahara (Morocco, Algeria). In R. T. Becker \& W. T. Kirchgasser (Eds.) Devonian events and correlations. Geological Society, London: Special Publication 278, 261-271.

Caputo, M. V., de Melo, J. G., Streel, M., Isbell, J. L., \& Fielding, C. (2008). Late Devonian and early Carboniferous glacial records of South America. Geological Society of America Special Papers, 441, 161-173.

Carmichael, S., Waters, J., Königshof, P., Suttner, T., \& Kido, E. (2019). Paleogeography and paleoenvironments of the Late Devonian Kellwasser Event: a review of its sedimentological and geochemical expression. Global and Planetary Change, 183. https://doi.org/10. 1016/j.gloplacha.2019.102984.

Cole, D., Myrow, P. M., Fike, D. A., Hakim, A., \& Gehrels, G. E. (2015). Uppermost Devonian (Famennian) to Lower Mississippian events of the western U.S.: stratigraphy, sedimentology, chemostratigraphy, and detrital zircon geochronology. Palaeogeography, Palaeoclimatology, Palaeoecology, 427, 1-19.

Corradini, C., Kaiser, S. I., Perri, M. C., \& Spalletta, C. (2011). Conodont genus Protognathodus and its potential as a tool for defining the Devonian/Carboniferous boundary. Rivista Italiana di Paleontologia e Stratigrafia, 117, 15-28.

Corradini, C., Spalletta, C., Mossoni, A., Matyja, H., \& Over, D. J. (2016). Conodonts across the Devonian/Carboniferous boundary: a review and implication for the redefinition of the boundary and a proposal for an updated conodont zonation. Geological Magazine, 154(4), 888-902.

Davoudzadeh, M. (1997). Iran. In E. M. Moores \& R. W. Fairbridge (Eds.) Encyclopedia of European and Asian regional geology (pp. 384-405). London: Chapman \& Hall.

Djafarian, A. (1973). Stratigraphie des series a brachiopodes du Paleozoique superieur dans le plateau central d'Iran. Thèse de Doctorat (pp. 1-72). Mention Sciences Naturelles, Universite Claude Bernard Lyon.

Falahatgar, M., Vachard, D., \& Sakha, L. A. (2015). The Tournaisian (Early Carboniferous) of the Kahanag section (central Alborz; Northern Iran); biostratigraphy with calcareous algae and foraminifers; palaeobiogeographic implications. Revue de Micropaleontologie, 58(3), 217-237.

Feist, R., Yazdi, M. \& Becker, T. (1999). First Late Devonian trilobites from Iran. Unesco-IGCP Project 421, Abstract Book, Peshawar Meeting 8-26 September 1999, 9-10. Peshawar.
Flajs, G., \& Feist, R. (1988). Index conodonts, trilobites and environment of the Devonian-Carboniferous boundary beds at La Serre (Montagne Noire, France). Courier Forschungsinstitut Senckenberg, 100, 53-107.

Gaetani, M. (1965). Brachiopods and molluses from Geirud Formation, Member A (Upper Devonian and Tournaisian). Rivista Italiana di Paleontologia e Stratigrafia, 71, 679-770.

Ghavidel-Syooki, M. (1995). Palynostratigraphy and palaeogeography of a Palaeozoic sequence in the Hassanakdar area, central Alborz range, Northern Iran. Review of Palaeobotany and Palynology, 86, 91-109.

Ghavidel-Syooki, M., \& Moussavi, M. J. (1996). Palynostratigraphy and paleogeography study of Padeha, Bahram, Shishtu (1 \& 2) and Sardar formations in the Howz-e-Dorah (east of Tabas) (pp. 45-46). Kerman: First Geological Congress of Iranian Universities [in Persian].

Ghods, P. (1982). Rugose Korallen des Givetium und Frasnium im Elburz-Gebirge (Nord-Iran). Dissertation zur Erlangung des Doktorgrades der Naturwissenschaften im Fachbereich Geowissenschaften der Universität Hamburg, 1-171.

Golonka, J., Ross, M. I., \& Scotese, C. R. (1994). Phanerozoic paleogeographic and paleoclimatic modeling maps. In Pangea: global enviroments and resources (Vol. M17, pp. 1-47). Canadian Society of Petroleum Geologists.

Habibi, T., Corradini, C., \& Yazdi, M. (2008). Famennian-Tournaisian conodont biostratigraphy of the Shahmirzad section, central Alborz, Iran. Geobios, 41, 763-777.

Hamdi, B., \& Janvier, P. (1981). Some conodonts and fish remains from Lower Devonian (lower part of the Khoshyeylaq Formation) north east Shahrud, Iran. Geological Survey of Iran, Report, 49, 195-210.

Hoseininezhad, S.M. (2006). Biostratigraphy of Late Devonian (Famennian) deposits in the East Alborz, based on goniatites, brachiopods and conodonts. PhD thesis, University of Isfahan, Iran. [in Persian].

Hairapetian, V., \& Yazdi, M. (2003). Late Devonian conodonts from Dalmeh section, northeastern Ardekan, Central Iran. Courier Forschungsinstitut Senckenberg, 245, 209-225.

Hairapetian, V., Yazdi, M., \& Long, J. A. (2000). Devonian vertebrate biostratigraphy of Central Iran. Records of the Western Australian Museum, Supplement, 58, 241-247.

Isaacson, P., Diaz-Martinez, E., Grader, G. W., Kalvoda, J., Babek, O., \& Devuyst, F. X. (2008). Late Devonian-earliest Mississippian glaciation in Gondwanaland and its biogeographic consequences. Palaeogeography, Palaeoclimatology, Palaeoecology, 268(3), 126-142.

Isaacson, P., Hladil, J., Shen, J., Kalvoda, J., \& Grader, G. (1999). Late Devonian (Famennian) glaciation in South America and marine offlap on other continents. Abhandlungen der Geologischen Bundesanstalt, 54, 239-258.

Jenny, J. G. (1977). Prècambrien et Palèozoique infèrieur de l'Elbourz oriental entre Aliabad et Sharhrud, Iran du nord-est. Eclogae Geologicae Helvetiae, 70, 761-770.

Kaiser, S. I. (2009). The Devonian/Carboniferous boundary stratotype section (La Serre, France) revisited. Newsletters on Stratigraphy, 43(2), 195-205.

Kaiser, S.I., Becker, R.T., Brice, D., Nicollin, J.-P., Legrand-Blain, M., Aboussalam, Z.S., El Hassani, A. \& Nübel, H. (2004). Sedimentary succession and neritic faunas around the Devonian-Carboniferous boundary at Kheneg Lakahal south of Assa (Dra Valley, SW Morocco). Documents de l'Institut Scientifique, Rabat, 19, 69-74.

Kaiser, S. I., Becker, R. T., Spalletta, C., \& Steuber, T. (2009). Highresolution conodont stratigraphy, biofacies and extinctions around the Hangenberg Event in pelagic successions from Austria, Italy and France. Palaeontographica Americana, 63, 97-139.

Kaiser, S.I., Aretz, M. \& Becker, R.T. (2016). The global Hangenberg Crisis (Devonian-Carboniferous transition): review of a first-order 
mass extinction. In R. T. Becker, P. Königshof, \& C.E. Brett (Eds.) (2016). Devonian climate, sea level and evolutionary events. Geological Society, London, Special Publications, 423, 387-437.

Kaiser, S. I., \& Corradini, C. (2011). The early Siphonodellids (Conodonta, Late Devonian-Early Carboniferous): overview and taxonomic state. Neues Jahrbuch für Geologie und Paläontologie Abhandlungen, 261, 19-35.

Kaiser, S. I., Kumpan, T., \& Cígler, V. (2017). New unornamented siphonodellids (Conodonta) of the lower Tournaisian from the Rhenish Massif and Moravian Karst (Germany and Czech Republic). Neues Jahrbuch für Geologie und Paläontologie, Abhandlungen, 286, 1-33.

Kaiser, S. I., Kumpan, T., \& Rasser, M. W. (2019). High-resolution conodont biostratigraphy in two key sections from the Carnic Alps (Grüne Schneid) and Graz Paleozoic (Trolp) - implications for the biozonation concept at the Devonian-Carboniferous boundary. Newsletters on Stratigraphy, 53, 249-274. https://doi.org/10.1127/ nos/2019/0520.

Kaiser, S. I., Steuber, T., \& Becker, R. T. (2008). Environmental change during the Late Famennian and Early Tournaisian (Late Devonian - Early Carboniferous) - implications from stable isotopes and conodont biofacies in Southern Europe. Geological Journal, 43, 241-260.

Karimi, L. (2001). Biostratigraphy of Middle-Upper Devonian rocks in Mighan area (Eart Alborz) based on conodonts and vertebrate remains. Unpublished master's thesis, Geological Survey of Iran, Earth Science Institute. Teheran [in Farsi].

Kimyai, A. (1972). Devonian plant microfossils from the central Elburz, Iran. Pollen and Spores, 14, 187-201.

Komatsu, T., Kato, S., Hirata, K., Takashima, R., Orata, Y., Oba, M., Naruse, H., Tha Hoa, P., Nguyen, P. D., Dang, H. T., Doan, T. N., Nguyen, H. H., Sakata, S., Kaiho, K., \& Königshof, P. (2014). DevonianCarboniferous transition containing a Hangenberg Black Shale equivalent in the Pho Han Formation on Cat Ba Island, northeastern Vietnam. Palaeogeography Palaeoclimatology Palaeoecology, 404, 30-43. https://doi.org/10.1016/j.palaeo.2014.03.021.

Lai, C.-K., Meffre, S., Crawford, A. J., Zaw, K., Xue, C. D., \& Halpin, J. A. (2014). The Western Ailaoshan volcanic belts and their SE Asia connection: a new tectonic model for the eastern Indochina block. Gondwana Research, 26(1), 52-74.

Lakin, J., Marshall, J., Troth, I. \& Harding, I. (2016). Greenhouse to icehouse: a biostratigraphic review of latest DevonianMississippian glaciations and their global effects. In R. T. Becker, P. Königshof, \& C. E. Brett (Eds.) (2016). Devonian climate, sea level and evolutionary events. Geological Society, London, Special Publications, 423, 439-467.

Liu, J., Qie, W., Algeo, J. T., Yao, L., Huang, J., \& Luo, G. (2016). Changes in marine nitrogen fixation and denitrification rates during the end-Devonian mass extinction. Palaeogeography Palaeoclimatology Palaeoecology, 448, 195-206.

McGhee, G.R., Clapham, M.E., Sheehan, P.M., Bottjer, D.J. \& Droser, M.L. (2013). A new ecological-severity ranking of major Phanerozoic biodiversity crises. Palaeogeography Palaeoclimatology Palaeoecology, $370(0), 260-270$.

Mohammadi, M. (2009). Biostratigraphy of Late Devonian-Early Tournaisian deposits (Jairud Formation), central Alborz. Unpublished PhD thesis, University of Isfahan. $165 \mathrm{pp}$. [in Persian].

Morzadec, P. (2002). Trilobites Asteropyginae devoniens d'Iran. Geobios, 35, 411-427.

Nazik, A., Königshof, P., Ariuntogos, M., Waters, J. A., Carmichael, S. K. (in press) Late Devonian ostracods (Crustacea) from the Hushoot Shiveetiin gol section (Baruunhuurai Terrane, Mongolia) and their palaeoenvironmental implication and palaeobiogeographic relationship. Palaeobiodiversity and Palaeoenvironments (in press). https:// doi.org/10.1007/s12549-020-00446-z
Paproth, E., Feist, R., \& Flajs, G. (1991). Decision on the DevonianCarboniferous boundary stratotype. Episodes, 14(4), 331-336.

Paschall, O., Carmichael, S. K., Königshof, P., Waters, J. A., Ta, P. H., Komatsu, T., \& Dombrowski, A. (2019). The DevonianCarboniferous boundary in Vietnam: sustained ocean anoxia with a volcanic trigger for the Hangenberg Crisis? Global and Planetary Change, 175, 64-81.

Peng, S., Geyer, G., \& Hamdi, B. (1999). Trilobites from the Shahmirzad section, Alborz Mountains, Iran: their taxonomy, biostratigraphy and bearing for international correlation. Beringeria, 25, 3-66.

Qie, W., Liu, J., Chen, J., Wang, X., Mii, H.-S., Zhang, X., Huang, X., Yao, L., Algeo, T. J., \& Luo, G. (2015). Local overprints on the global carbonate $\delta^{13} \mathrm{C}$ signal in Devonian-Carboniferous boundary successions of South China. Palaeogeography Palaeoclimatology Palaeoecology, 418, 290-303.

Racki, G., Rakociński, M., \& Marynowski, L. (2018). Anomalous Upper Devonian mercury enrichments: comparison of inductively coupled plasma-mass spectrometry (ICP-MS) and AAS analytical data. Geological Quarterly, 62(3), 487-495. https://doi.org/10. 7306/gq.1419.

Ramezani, J., \& Tucker, R. D. (2003). The Saghand region, Central Iran: $\mathrm{U}-\mathrm{Pb}$ geochronology, petrogenesis and implications for Gondwana tectonics. American Journal of Science, 303, 622-665.

Reyer, D., \& Mohafez, S. (1970). Une premiere contribution des accords NIOC-ERAP a la connaissance geologique de 1' Iran. Review Institute de France Petrology, 25, 979-1014.

Sandberg, C. A., Morrow, J. R., \& Ziegler, W. (2002). Late Devonian sea-level changes, catastrophic events, and mass extinctions. Geological Society of America Special Papers, 356, 473-487.

Sardar Abadi, M., Da Silva, A.-C., Mossadegh, H., Spassov, S. \& Boulvain, F. (2015). Lower Carboniferous ramp sedimentation of the central Alborz Basin, Northern Iran: intergrated sedimentological and rock-magnetic studies. In A. C. Da Silva, M. T. Whalen, J. Hladil, L. Chadimova, D. Chen, S. Spassov, F. Boulvain, \& X. Devleeschouwer (Eds.) Magnetic susceptability application: a window onto ancient environments and climate variations. Geological Society, London, Special Publication, 414, 73-91.

Sartenaer, P. (1964). Decouverte d'un niveau a plantes d'age Famennien superieur dans l'Elbourz central (Iran). Rivista Italiana di Paleontologia, 70, 651-655.

Scotese, C. R. (2001). Atlas of Earth history paleogeography (Vol. 1). Arlington: Paleomap Project.

Sepkoski, J. J. (1996). Patterns of Phanerozoic extinction: a perspective from global data bases. In O. H. Walliser (Ed.) Global events and event stratigraphy in the Phanerozoic (pp. 35-51). Berlin: Springer.

Sharkovski, M., Susov, M., \& Krivyakin, M. (1984). Geology of the Anarak area (Central Iran), explanatory text of the Anarak quadrangle map. Geological Survey of Iran, Scale, 1: 250. 000, V/O Technoexport, Report, 19. Tehran, p. 143.

Spalletta, C., Perri, M. C., Over, D. J., \& Corradini, C. (2017). Famennian (Upper Devonian) conodont zonation: revised global standard. Bulletin of Geosciences, 92(1), 31-57.

Stepanov, D.L. (1971). Carboniferous stratigraphy of Iran. Sixme Congress de Stratigraphie et de Geologie du Carbonifere, Sheffield 11th to 16th September 1967, 4, 1505-1518. Publishing Company "Ernest van Aelst"; Maastricht.

Stocklin, J. (1968). Structural history and tectonic of Iran: a review. American Association of Petroleum Geologists Bulletin, 52, $1229-1258$.

Streel, M., Caputo, M. V., Loboziak, S., Melo, J., \& Thorez, J. (2001). Palynology and sedimentology of laminites and tillites from the latest Famennian of the Parnaíba Basin, Brazil. Geologica Belgica, 3(1-2), 87-96.

Streel, M., Caputo, M. V., Loboziak, S., \& Melo, J. H. G. (2000). Late Frasnian-Famennian climates based on palynomorph analyses and 
the question of the Late Devonian glaciations. Earth-Science Reviews, 52(1), 121-173.

Streel, M. \& Loboziak, S. (1996). Chapter 18B, Middle and Upper Devonian miospores. In J. Jansonius, D.C. McGregor (Eds.) Palynology: principles and applications, 2. American Association of Stratigraphic Palynologists Foundation, pp. 575-587.

Stribrny, B., Korn, D., Königshof, P., Erbacher, J. \& Blumenberg, M. (in press). Die Kupfererzlagerstätte Marsberg. Zeitschrift für angewandte Geologie.

Torsvik, T. H., \& Cocks, L. R. M. (2004). Earth geography from 400 to 250 ma: a palaeomegnetic, faunal and facies review. Journal of Geological Society, 161, 555-572.

Ueno, K., Watanabe, D., Igo, H., Kakuwa, Y. \& Matsumoto, R. (1997). Early Carboniferous Foraminifera from the Mobarak Formation of Shahmirzad, Northeastern Alborz Mountains, Northern Iran. In C.A. Ross, J.R.P. Ross, \& P. L. Brenckle (Eds.) Late Paleozoic foraminifera, their biostratigraphy, evolution, and paleoecology, and the mid-Carboniferous boundary. Cushman Foundation for Foraminiferal Research Special Publication, 36, 149-152.

Walliser, O. H. (1996). Global events in the Devonian and Carboniferous, global events and event stratigraphy in the Phanerozoic (pp. 225-250). Springer.

Webster, G. D., Maples, C. G., \& Yazdi, M. (2007). Late Devonian and early Mississippian echinoderms from central and Northern Iran. Journal of Paleontology, 81, 1101-1113.
Weddige, K. (1984). Zur Stratigraphie und Paläogeographie des Devons und Karbons von NE-Iran. Senckenbergiana lethaea, 65, 179-223.

Wendt, J., Hayer, J., \& Bavandpour, A. K. (1997). Stratigraphy and depositional environment of Devonian sediments in northeast and east-central Iran. Neues Jahrbuch für Geologie und Paläontologie, Abhandlungen, 206, 277-322.

Wendt, J., Kaufmann, B., Belka, Z., Farsan, N., \& Karimi, B. A. (2002). Devonian/Lower Carboniferous stratigraphy, facies patterns and palaeogeography of Iran. Part I. Southeastern Iran. Acta Geologica Polonica, 52, 129-168.

Wendt, J., Kaufmann, B., Belka, Z., Farsan, N., \& Karimi Bavandpur, A. (2005). Devonian/Lower Carboniferous stratigraphy, facies patterns and palaeogeography of Iran. Part II. Northern and Central Iran. Acta Geologica Polonica, 55, 31-97.

Yazdi, M. (1999). Late Devonian-Carboniferous conodonts from Eastern Iran. Rivista Italiana di Paleontologiae Stratigrafa, 105, 167-200.

Yazdi, M., \& Turner, S. (2000). Late Devonian and Carboniferous vertebrates from the Shishtu and Sardar formations of the Shotori Range, Iran. Records of the Western Australian Museum, Supplement, 58, 223-240.

Ziegler, W., \& Sandberg, C. A. (1990). The Late Devonian standard conodont zonation. Courier Forschungsinstitut Senckenberg, 121, $1-115$.

Publisher's note Springer Nature remains neutral with regard to jurisdictional claims in published maps and institutional affiliations. 